\title{
Industry's pledges to limit harms of alcohol are unlikely to work, research finds
}

We would like to make it clear that the comments from The Portman Group at the end of this Research News story (BMJ 2015;350:h1671, doi:10.1136/bmj.h1671) were made in response to the research published in Addiction, and not to the Analysis published in The BMJ.
Cite this as: BMJ 2015;350:h1692

๑ $\odot$ BMJ Publishing Group Ltd 2015 